\title{
From the Avalanche to the Game: White-Collar Offenders on Crime, Bonds and Morality
}

\author{
Joost H. R. van Onna ${ }^{1,2}$
}

Published online: 18 May 2020

(C) The Author(s) 2020

\begin{abstract}
In order to understand the mechanisms that underlie involvement in white-collar crime on a personal level, 26 offenders convicted of a white-collar offence were interviewed. Building on theory and research from white-collar criminology, life-course criminology and moral psychology, findings show that a combination of criminogenic circumstances, weakened social bonds and adjusted moral ideas lead offenders down different pathways into white-collar offending. Although the process of crime involvement seems highly context-dependent in some instances, the interviews indicate that crime involvement is more commonly part of a long-running process, in which social bonds have weakened or moral ideas have been adjusted, which in turn influenced the decision to engage in the white-collar offence. Along with the limitations of the study and the directions for future research, the paper discusses the implications of the findings for white-collar crime research, in particular the complex role of morality in white-collar crime involvement.
\end{abstract}

Keywords White-collar crime $\cdot$ Social bonds $\cdot$ Morality $\cdot$ Life-course $\cdot$ Interview

\section{Introduction}

The role of personal experiences and moral views of those who become involved in white-collar crimes, such as tax evasion, insider trading or embezzlement, remains poorly understood. ${ }^{1}$ Do individuals become criminally active in response to a specific

\footnotetext{
${ }^{1}$ In this study an offence-based definition of white-collar crime is adopted (following Edelhertz's definition, [1]), to reflect the heterogeneous nature of white-collar crime in contemporary societies (see also: [2]). Still, the large majority of this study's respondents would also fall within an offender-based approach, as they committed the white-collar offences during their occupation in high-trust positions in organization ([3]; see method section).
}

Joost H. R. van Onna

J.van.onna@vu.nl

1 Department of Criminal Law and Criminology of VU University, Amsterdam, The Netherlands

2 Netherlands National Public Prosecutor's Office for Serious Fraud, Environmental Crime and Asset Confiscation, Amsterdam, The Netherlands 
situation, or is their crime involvement part of a long-running process? And what are the social and moral mechanisms that account for this process? In white-collar crime literature, the involvement in white-collar crime is typically conceptualized as the outcome of differential exposure to criminogenic situational forces, such as corporate cultural values and businesses' practices (e.g. [3-5]), organizational opportunity structures (e.g. [6]) or economic strains (e.g. [7]). While these situational forces are highly important for understanding crime involvement, white-collar scholars stress that without taking offenders' background and cognitions into account we cannot fully understand how offenders react to or perceive criminogenic environments, why individuals become attracted to criminogenic environments in the first place, and how and why persons eventually fold under pressure or take advantage of criminal opportunities (e.g. $[8,9])$.

A relevant perspective on these questions is offered by life-course criminology (e.g. $[2,10])$. In this perspective, crime involvement of offenders is conceptualized as a developmental pattern across the life span [11]. For some offenders earlyemerging individual characteristics and social influences lead to an early crime onset, followed by a stable pattern of transgressive behaviour (e.g. [12]). For other offenders changes in their personal or professional life, such as events, social interactions or socialization processes in adulthood can become turning points and lead to crime involvement (e.g. [13]). The few white-collar crime studies that have taken a life-course perspective show that for most white-collar offenders the process of crime involvement starts in adulthood and appears to be highly dependent on business-related circumstances, while a minority of white-collar offenders has engaged in crime since early stages of life $\left[2,14,15{ }^{2}{ }^{2}\right.$

A personal factor that is highlighted in life-course criminology that may play a significant role in white-collar crime involvement, is a white-collar offender's social embeddedness [16]. Social control theorists argue that those who experience weak ties to their social and work environment and conventional society more generally have an increased risk of selecting into and actually taking advantage of criminogenic circumstances [16-18]. Sampson and Laub (2005, p. 167; see also [18], p. 19) propose that a weakened bond to conventional society may be the result of low self-control or problematic socialization in early stages of life, but it may also be the outcome of life-events and developments in adulthood. Whitecollar crime researchers have, for example, argued that criminogenic socialization processes within organizations may weaken individuals' bond to conventional society [19-21]. While more research is needed, research suggests that whitecollar offenders may experience a deterioration of social bonds and that this attenuation increases the chance of white-collar crime [22-24]. The few qualitative studies that have focused on social bonds and white-collar crime, suggest that business crises or financial problems, can negatively influence social bonds and that these experiences can be seen as negative turning points in offenders' lives,

\footnotetext{
${ }^{2}$ For example, in one of the most elaborate studies, Weisburd et al. [2] identify several white-collar offender types that differ in their criminal development. 'Crisis responders' engage in crime in response to some kind of perceived crisis, while 'opportunity takers' seem to respond to unusual sets of opportunities for white-collar crimes. Another group of offenders, is labelled as 'opportunity seekers', who follow an intermittent pattern of offending behaviour that suggests they seek out opportunities to commit crime. The last group of offenders is labelled as 'stereotypical criminals', who are characterized by active criminal careers.
} 
ultimately leading to white-collar offending $[25,26]$. However, such qualitative studies are rare and to date relatively little is known about how the thoughts and actions that lead white-collar offenders to engage in crime are shaped by developments across their lives [27, 28].

A second personal factor that is potentially important in understanding whitecollar crime involvement is highlighted in psychology, business ethics and criminology: an individual's personal morality. An extensive body of literature, stresses that the risk of committing white-collar deviance and crime increases sharply when it has been permitted (or not excluded) on moral grounds (e.g. [29-31]).

This literature offers different perspectives on the role of morality in whitecollar crime involvement. The white-collar crime literature has usually contended that white-collar offenders neutralize or justify crime involvement during or after the act by normalizing or decriminalizing the criminal act (e.g. $[9,29])$. Neutralization theory proposes that offenders use mental strategies, called neutralization techniques, that allow offenders to view their engagement in an act of crime as justified ([32]; see also: [9]). Sykes and Matza [32] identify five techniques: appeal to higher loyalty, denial of responsibility, denial of injury, denial of victim and condemnation of condemners. ${ }^{3}$ While initially developed to understand juvenile delinquency, neutralization techniques have been found particularly relevant for understanding white-collar crime. With a few notable exceptions (e.g. $[36,37])$, most studies based on interviews with white-collar offenders have suggested that their narratives about crime involvement should be understood as ways of neutralizing during the criminal act or as ways to justify their crime involvement towards themselves or a social audience after the criminal act (e.g. $[38,39]$; for an overview of this literature, see [40]).

Despite its popularity in white-collar crime research, scholars have warned that there is little evidence for the causal and temporal link between neutralizations and offending ([41]; but see: $[42,43])$. The theory has also been criticized on theoretical grounds, because it builds on the premises that all individuals (including offenders) have similar, stable and prosocial ideas about what is permissible behaviour, and that because of this all individuals and offenders need to reduce psychological tension by normalizing or decriminalizing the criminal act $[34,44]$. Consequently, the theory does not allow for the existence of personal differences between offenders, for changes in moral ideas over time and for psychological processes other than neutralization techniques to be involved in (un)ethical decision-making.

In contrast, psychology and business ethics scholars propose that morality plays a more dynamic and multifaceted role. These scholars highlight, for example, the role of personal norms, moral self image and the experienced legitimacy of rules and regulations, when understanding why persons engage in financial-economic misconduct (e.g. [45-47]). In one of the most prominent theories on (im)moral behaviour in psychology, Rest [48] identifies four psychological processes that

\footnotetext{
${ }^{3}$ Many more neutralization techniques have been identified since, such as metaphor of the ledger [33] and defence of necessity [34]. A recent systematic review of the neutralization literature counts more than sixty techniques [35].
} 
must be in place for people to act morally, and incorporates them in one comprehensive theory. When one or more of these processes fail, the risk of misconduct increases. First, when a person is not sensitive to the moral nature or the consequences of his fraudulent actions, the risk of fraud would increase ([48], p.5; moral sensitivity). Second, an individual's attitudes to and norms regarding what is permissible conduct in the financial-economic realm may not be prosocial and facilitate fraudulent behaviour ([48], p. 8; moral judgement). However, third, even if a fraudulent act is regarded as impermissible under normal circumstances, a person may change his moral view in a specific situation and choose another valued option over obeying the law ([48], p. 9: moral motivation). Finally, an individual may lack the moral restraint necessary to resist temptation at a specific time and place ([48], p. 13, 15; moral character). In Rest's theory, the decision to engage in immoral behaviour is not only dependent on the complexities of the specific (criminogenic) situation, but also on the individual's background, cognitions and personal life experiences [48]. In comparison to neutralization theory, Rest's theory thus proposes that personal morality plays a more complex, dynamic and varied role, allowing for inter- and intra-individual differences.

Rest's model provides a well-researched framework for understanding workplace-related misconduct, but this body of research is almost exclusively experimental in nature (see: [49, 50]). While the internal validity of these studies is strong, they typically have limited external and ecological validity [51]. Under real-life circumstances, the four psychological processes are likely to occur and influence each other in unique ways, but the way in which this may occur is largely unknown. Given the comprehensive nature of the theory and the strong empirical evidence, Rest's theory is utilized as a framework for the current exploratory study.

Taken together, while the literature shows that criminogenic contexts, bonds and morality are all possibly important factors in white-collar offending, to date it is poorly understood how these factors interact and contribute on the individual level to white-collar offending. Building on notions from white-collar crime theory [9], social control theory [16, 18] and moral psychology [48], 26 offenders convicted of a white-collar offence were interviewed in order to examine the involvement process underlying the white-collar offence. The research question is: How do criminogenic contexts, bonds and morality contribute to white-collar crime involvement, and how do these factors interact in that process?

\section{Data and Method}

\section{Procedure}

Following an offence-based approach to white-collar crime ([1]; see also footnote 1), the inclusion criterion for the study was that participants had been irrevocably convicted for a white-collar offence punishable under Dutch criminal law. In 2015 , two methods were started to select participants falling within this inclusion criterion, with the aim of interviewing a total of 25 participants, a sample size 
consistent with qualitative research in the field [52]. ${ }^{4}$ In the first method, a sample of individuals who were irrevocably convicted for a white-collar offence was selected from the Public Prosecution Service Database $(n=180)$, with permission from the Netherlands Public Prosecution Service. The potential participants received a letter from the researcher, outlining the research goals and the request for an interview. A response rate of around 15\% was expected, allowing us to reach intended number of respondents. However, selecting respondents in this way proved challenging and time consuming (e.g. undeliverable letters). In the first method, 15 individuals agreed to participate (response rate: 8\%). Instead of selecting and approaching more participants from this research sample by letter, a second method was applied. With permission of the Netherlands Prison Authority, a sample of individuals who were irrevocably convicted for a whitecollar offence and were imprisoned in Dutch prisons was selected $(n=115)$. Potential participants were approached by their case manager with an introductory letter from the researcher, outlining the research goals and the request for an interview. Eleven respondents $(n=11)$, imprisoned in eight different prisons throughout the Netherlands, agreed to take part in the study. The recruitment of new participants was stopped at 11 participants $(n=26[15+11])$, when a point of saturation was reached and no new themes arose from additional interviews. None of the respondents were paid or received any other form of incentive.

The study design, procedure and interview set-up were reviewed and approved by the Ethical Committee of the Department of Criminal Law and Criminology of VU University in Amsterdam (The Netherlands).

\section{Respondents}

Respondents were convicted between 2008 and 2015 for a variety of white-collar offences. Fourteen respondents were convicted for tax crimes, mostly corporate tax and turnover tax offences. Respondents were (in some case at the same time) convicted for tax-related offences, such as money laundering $(n=4)$ and bankruptcy fraud $(n=1)$. Yet others were convicted for swindles $(n=9)$, securities fraud $(n=1)$, insider trading $(n=1)$ and credit-card fraud $(n=1)$. What the respondents had in common was that they were typically convicted for a serious form of white-collar crime in the sense that the crimes resulted in big financial losses and/or lasted up to several years. For example, 18 respondents $(69 \%)$ indicated that defrauded money exceeded one hundred thousand euros, typically several hundreds of thousands and in some cases millions of euros (several respondents did not want to elaborate on the financial damage of their offences).

Participants are almost exclusively male $(n=24 ; 92 \%)$ and were middle-aged at the time of the interview (30-39: 19\%; 40-49: 31\%; 50-59: 27\%; 60+: 19\%). Twenty respondents $(77 \%)$ held an executive organizational position as director or company owner at the time of the offence (see Sutherland's definition of white-collar crime [1983] and Footnote 1), mostly in smaller- to medium-sized companies (that make up the large majority of companies in the Netherlands, see [53]). One respondent was

\footnotetext{
${ }^{4}$ While the subsamples differ in selection method, a comparative analysis showed that the respondents of both subsamples did not significantly differ on key measures (criminogenic contexts, bonds, morality).
} 
employed in a large organization at the time of the offence and five respondents were involved in the selection offence without being formally employed or holding a senior managerial position. The type of economic activity and economic sector that participants' companies were engaged in is diverse, ranging from transport, the entertainment industry, ICT and agriculture to consultancy.

A comparative analysis between the sample and a contemporary, large-scale sample of white-collar offenders in the Netherlands (for a detailed description of the research sample, see [15]), shows that the offenders in the current sample are similar to those in the larger sample in terms of selection white-collar offences, criminal career dimensions, sociodemographic characteristics and organizational profile [54]. ${ }^{5}$

\section{Interviews}

The semi-structured interviews were conducted over a ten-month period between 2015 and 2016. Twenty-five interviews were conducted face-to-face; one respondent did not want to be interviewed in person and was interviewed by telephone. All interviews were tape-recorded, except the telephone interview during which the researcher was able to make extensive notes. The average duration of the interviews was slightly over $100 \mathrm{~min}$, with a total of 45 interview hours.

The interviews were conducted in the participant's place of preference, typically at their home or business and in a few cases at the university. The participants who were incarcerated at the time of the interview were interviewed in closed prison visiting rooms, which provided the necessary privacy. After some informal social talk, the interview started out with an introduction about the research and an explanation of the participants' rights. The respondents were then asked to sign a consent form. The respondents were invited to recount, in their own words, the events that had led them to the selection offence. A topic list with themes and concepts relevant to the research question was used. Participants were asked about the selection offence, the personal and business circumstances surrounding the offence, their lives with a focus on worklife experiences, and prior contacts with regulatory bodies and the justice system. They were also asked to reflect on laws and regulations that governed their businesses, the social norms in their business environment and their personal attitudes. At the end of the interview, respondents were asked whether they had anything to add. They were then thanked for their participation, after which the interview was closed.

The atmosphere during the interviews tended to be relaxed and open. When asked about the reasons for participating, respondents indicated that (among other things) they wanted to help the research project; come clean after a life of crime; escape boredom in prison; do a "good deed"; warn other entrepreneurs of their mistakes; or that they saw the interview as an opportunity for self-reflection. Respondents seemed to speak freely about the selection offence, earlier life experiences and their attitudes and beliefs about doing business and complying with the law. They also tended to talk openly about their intentions to engage in the offence and referred repeatedly to earlier misconduct.

\footnotetext{
${ }^{5}$ For example, in both samples the most prevalent selection offences are tax crimes; both samples consist mainly of middle-aged men, contain a comparable percentage of offenders who occupied a high-trust position in organizations, such as director and company owner, and both samples are similar in the ratio between offenders who started to engage in crime in their youth and those who started in adulthood.
} 


\section{Analytic Strategy}

The tape-recorded interviews were transcribed verbatim. The transcriptions and interview notes were read repeatedly, coded by theme and sub-theme and entered in a qualitative data matrix for further analysis. The themes and sub-themes were all related to the offence, the context and events surrounding the offence, earlier developments in their lives, prior crime and law violations, attitudes and norms regarding the selection offence, and laws and regulations in the financial-economic realm. Then, using notions from Cressey's work [9], the way respondents described the circumstances leading up to their selection offence was analysed. Using concepts from Sampson and Laub's work [16, 55], Hirschi's research [18] and Rest's theory [48], the manner respondents described their bond to society and talked about their moral considerations in relation to their rule-violating behavior were scrutinized. In the analysis, important themes and sub-themes (e.g. the type of criminogenic pressure they experienced during the selection offence) were identified. Focusing on a specific (sub-)theme, the transcripts were analysed in more detail. Finally, the narratives per participant were studied in order to get a full understanding of how context, bonds and morality interacted, and accounts that were illustrative of key themes were identified.

\section{Findings and Analysis}

\section{Change, pressure and opportunity}

The events, circumstances and developments surrounding the selection offences varied markedly between respondents. The narratives, however, also showed many strong similarities. Participants seemed to go through a three-step process leading up to the white-collar offence (see Fig. 1). First, 20 respondents (77\%) describe how in the circumstances leading up to the selection offence, a change of some sort occurred in their economic or private life. Sometimes the change happened gradually, for example a progressively worsening economic situation, or a process in which businessmen join forces first in a legitimate business to later become partners in crime. However, in most instances of change ( $n=17,69 \%)$, there was (also) a more or less abrupt event closely related to the selection offence: an economic or personal crisis, the launch of a new company, meeting a co-conspirator, or a request from an important friend or business associate.

Take the narrative of John who was working as a tax advisor when a business acquaintance asked him for legal advice in order to set up a trading company in another European country. ${ }^{6}$ Even though this type of business was new to him, he decided to run the company himself in parallel to his advisory work:

I don't just want to do advisory work until my retirement. I am also an entrepreneur in the sense that I like to see whether I can earn something through trade, or

\footnotetext{
${ }^{6}$ All names and other identifiable characteristics of the interviewees have been changed to safeguard their anonymity.
} 
other businesses in which there is money to be made. Not that I'm such a moneygrubber, but I like challenges.

Although he recognized that the fiscal construction his company was part of was perhaps dubious, he argued: "I don't need to be the police officer and to ask them: 'Do you have a permit? Do you pay your taxes?' That's not my role." Eighteen months after the company launch, he was arrested in the Netherlands in possession of a large sum of undeclared money. He was convicted for his involvement in an international tax-evasion and money-laundering scheme.

In a second phase, the changes developed into criminogenic pressure [9]. Respondents indicated that they experienced one of three types of criminogenic pressures (or a combination): economic or personal strain, social pressure and temptation. One out of three respondents (35\%) experienced some form of strain [2, 7]. They tried to minimize economic losses or (re)gain monetary resources. Others suffered a full-blown crisis and were afraid of losing everything they had built up, which subsequently drove them to break the law.

The second criminogenic pressure that respondents experienced was some form of social pressure from other deviants (50\% of the respondents). In seven narratives, the respondents experienced social pressure from business partners, associates and acquaintances who were involved in the offence [5]. In the other six cases, the conspirators seemed to be in control and were able to persuade, lure or fool respondents into partaking in the fraud. In these instances, the confidants were close to the respondents, well-trusted individuals who were

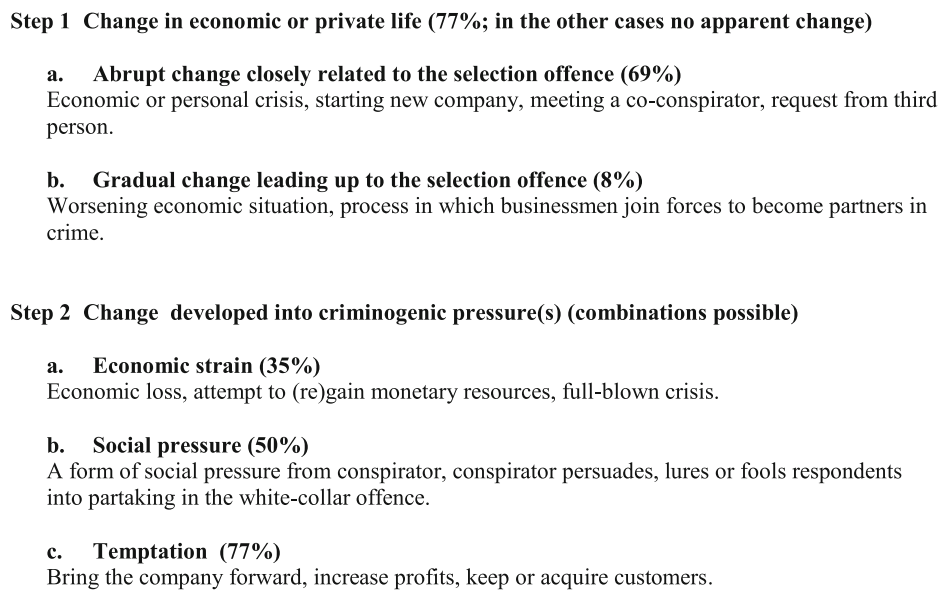

Step 3 Opportunity is taken to resolve, reduce or take advantage of criminogenic pressure

a. Existing opportunity in organizational position $(81 \%)$

Organizational position that respondents occupy offer crime opportunities.

b. New opportunity as result of changes in economic or private life $(\mathbf{1 9 \%})$

Conspirator or new circumstances provide new opportunities for a white-collar offence.

Fig. 1 Three steps leading to white-collar offences $(n=26)$ 
important to them. The third criminogenic pressure that respondents experienced was temptation [2]. Rather than avoiding a loss, fighting oneself out of a crisis or complying with other deviants, the narratives show that the most common pressure was temptation. Twenty participants $(77 \%)$ indicated they wanted to help the company forward, increase profits, make a financial profit or keep or acquire customers.

A clear illustration of this latter dynamic can be seen in the case of Lawrence, the owner of a wholesale export company. He was approached by a new foreign customer, who asked him to open a new line of trade. This potentially lucrative customer suggested using two bills of lading to avoid high import taxes in his country. While he had broken (minor) trade rules before, he was at first reluctant. However:

One is always quickly inclined to take orders. Sometimes too quickly. Without really thinking: what are the consequences? In hindsight, I could have known. By under-invoicing you're of course not providing the correct information to that country, to customs or local authorities. But then you're keen to get the order. You want to help the customer. And so you go along with it.

He falsified the bills of lading and created a double administration to cover up the fraud. He was convicted for violating a customs law and making false statements.

Lawrence's case illustrates how participants - motivated to resolve, reduce or take advantage of criminogenic pressures - exploited existing opportunity structures or sought out new ones (the third step). In some instances, the aforementioned change provided respondents with a new criminal opportunity (e.g. a third party that set up a fraudulent scheme), but in 21 instances (81\%) their organizational position offered them the necessary opportunity. Being the director or owner of a company, most respondents were in a position of trust, had discretional power and were not closely monitored [9, 56]. The narratives of the business owners and directors indicate that they typically knew how to take advantage of criminal opportunities from their experience and knowledge of running their business legally (e.g. knowledge of the tax system). ${ }^{7}$

An illustrative example of how participants used available opportunities and knowledge, is that of Rudolph who was convicted for making false tax declarations. This experienced but self-declared "lousy businessman" invested private money in his new business. When a highly anticipated contract fell through, his business went downhill and he started to commit fraud:

A little at a time. Well, a little, for many it is a lot of money. It was a process that sneaked in. It was easy and it allowed me to save my company. It did bother me. But I did not embezzle one million in one go. I made 100 fake invoices and

\footnotetext{
${ }^{7}$ Participants who were involved in more complex schemes also gathered additional knowledge through prior crimes or from (more experienced) white-collar offenders who participated in the selection offence [5].
} 
maybe 40 incorrect tax declarations. You see, I had two companies. And when it worked with one of them, I thought: I could also try it with the other.

This account also illustrates how the selection offences often started small, with one fake invoice, an incorrect declaration or a minor favour. That first small step made the second step easier, and when they were not caught, participants continued what they had started. The availability of criminal opportunities and the fact they were not caught were critical in this early stage, because it allowed the respondents to continue where they may otherwise have had to stop.

\section{Personal Background and Cognitions}

The narratives of John, Lawrence and Rudolph highlight the significance of criminogenic contexts for white-collar crime involvement. Without change, strain, social pressure or temptation and deprived of an opportunity, white-collar crime involvement may have been unlikely, smaller in scale or even impossible. However, without taking participants' background (bonds) and cognitions (morality) into account, we cannot fully understand how and why they end up in a criminogenic context in the first place, and how and why they engage in the selection offence.

The analysis of the narratives illustrates that the selection into and actually taking advantage of criminal opportunities ranges from highly situational processes to longrunning processes that went beyond the immediate criminogenic context. In the first section of this paragraph (Situational Crime Involvement), the cases of crime involvement that seem highly situational in nature are described. The narratives of a minority of respondents show how criminogenic developments surrounding the selection offence affected their bond to conventional society and their otherwise law-abiding moral views. In the second section (Crime Involvement Beyond the Immediate Context), the cases of crime involvement that seem to go beyond the criminogenic developments surrounding the selection offence are described. In two separate subparagraphs, the analysis focuses on the ways bonds and morality appear to have been adjusted before the selection offence and seem to have influenced how and why they ended up in a criminogenic context and how and why they engaged in the selection offence.

\section{Situational Crime Involvement}

The narratives of a six respondents (23\%) illustrate how changing personal and economic circumstances cause pressure and can weaken bonds in the period (immediately) leading up to the selection offence. These participants described themselves as generally law-abiding citizens and labelled the fraudulent acts they committed as impermissible under normal circumstances. For example, two respondents experienced highly stressful events in their personal and business lives which dramatically impacted them over a relatively short period of time. During this process, they appear to have become estranged from their social surroundings $[16,18]$. In their isolation, the participants seem to have lost their moral restraint ([48, 57]: moral character) and to have chosen an option they deemed important at that time, such as loyalty to their company or protecting their livelihood, over obeying the law ([48]: moral motivation). 
An illustrative example of how a crisis can lead to white-collar crime is the case of Fred. Over the course of two years, the world of this entrepreneur, who successfully built his own ICT company and had always been close to his family and customers, changed dramatically. Changes in his private life - the birth of his first son, the buying of a new house, the death of his father-in-law - strained his marriage. To make matters worse, during this period in which he already felt isolated, his uncle, who was a father figure to him, died. That is when he started to neglect his business:

I lost some loved ones... who were pillars in my life, and to whom I would turn when I was in trouble. But when those people are not there anymore. I became more and more introvert, because I did not want to show my ex-wife that things were not going well, she was already going through a tough time. And then I wanted to tie up all the loose ends and everything went wrong.

His private and economic life became even more stressful: "I felt like that little snowball had become an avalanche." He started to submit false declarations to the tax authorities to keep his head above water:

I had a house, I had my ex-wife, I had two children. I also had a face to lose, I had to do it. Interviewer: You had your responsibilities... Fred: That was my way of justifying it. Some people call it self-defence. It was me or him. And I respect the fact that you put yourself first... or your child. It may sound stupid, but otherwise you wouldn't be around anymore (...) Interviewer: What were your motives? Fred: It was entirely for myself, to save my company and my private life.

His company still went bankrupt and he was convicted of tax fraud. ${ }^{8}$

White-collar crime involvement also seems to be of a situational nature for two participants who were in a transitional phase at the time of the selection offence. After a (series of) event(s) had changed the direction of their lives and weakened social and economic ties, they engaged in a fraudulent activity they were unlikely to have engaged in during other stages of their lives. In these instances, respondents reported that they were asked by a third party to become part of or help out in a company that they knew little about but in which they eventually carried out fraudulent activities. In all cases, the respondents trusted the inviting party despite being aware of the fact that these individuals had come into contact with the justice system. Although these respondents were irrevocably convicted, they did not seem to take full responsibility for the legal and moral consequences of their actions, arguing that they were insufficiently aware of or simply ignored irregularities ([48]: moral sensitivity, moral judgement).

Take the case of Mary who lost her job after having been steadily employed for over 30 years (her 25-year relationship had ended a few years earlier). These events altered

\footnotetext{
${ }^{8}$ Fred seems to explicitly refer to a mental strategy he employed during the act to justify his actions to himself, a neutralization technique called defence of necessity [34] or appeal to higher loyalty [32]. The discussion section provides a more detailed discussion of the merits of neutralization theory for the current findings.
} 
her stable and conventional life: she went on social benefits, moved around multiple times and was convicted of a drug charge. During this turbulent transitional period, she met her new partner, a businessman who had been convicted of fraud: "He already had a bit of a reputation as a con man." They set up a company with the severance pay from her last job. Although she was a "working girl" and knew little to nothing about running a business, the company was put in her name because her husband had been involved in the bankruptcy of another company:

Suddenly they said that I had been involved in fraud and that I had signed false bills. It kind of just happened. Interviewer: What do you mean? Mary: I didn't really know that I had signed anything that was fraudulent or that would not be paid. (...) The judge said that I should never have let the company be placed entirely in my name. Well of course, if I had known everything in advance!

Mary and her husband were convicted of a scam worth hundreds of thousands of euros. ${ }^{9}$

\section{Crime Involvement Beyond the Immediate Context}

In the case of participants such as Fred and Mary, little in their lives before the selection offence would suggest that one day they would get involved in a serious white-collar offence. The narratives of the majority of respondents $(n=20 ; 77 \%)$, however, suggest a different, less situational involvement process. They not only experienced criminogenic changes, pressures and opportunities before, but they all referred to earlier (typically undetected) fraudulent misconduct: the selection offence was not an isolated affair. What these respondents also have in common is that prior to the selection offence their bond to conventional society seems to have been weakened and/or that their attitudes to and norms regarding what is permissible behaviour in the financial-economic realm appear to have been adjusted.

The Role of Weakened Bonds beyond the Immediate Context The narratives of 19 participants $(73 \%)$ indicate that their bond to their social and economic surroundings and to the (moral) standards of conventional society had been attenuated ([16]; see also, $[17,18])$. Ties in their social life, such as to their partner, family and local community, and particularly ties in their professional life seem fluid. Many respondents regularly changed businesses, owned several companies at once, experienced bankruptcies, started new companies, shifted executive positions frequently and were active in several and sometimes widely distinct economic sectors.

One such example is James, who was a successful entrepreneur before he became involved in investment and tax fraud. Recounting the many different companies and girlfriends he had over the years, he says his life is different from his conventional background and upbringing:

\footnotetext{
${ }^{9}$ Mary's statements about not knowing what was going on may be interpreted as a mental strategy to deny responsibility [32]. The discussion section provides a more detailed discussion of the merits of neutralization theory for the current findings.
} 
That is my base and where do I stand now? It is totally different. (...) No quiet conventional family life. I tried though. (...) But what I do see is that there is a sort of parallel between my current private and professional life. A kind of unrest. I am 46 and neither my private nor my professional life are on track. But meanwhile I've had a wonderful life. I've travelled the world and indulged in everything that's sinful - except drug use. (...) I have been strong as well [in resisting drugs]. But still it makes me wonder, why was I unable to resist temptation in other areas?

It all went wrong, he says, when he met his business associate and later partner-incrime: "It really went wrong because... well, when I think about it... because of meeting the wrong person at the wrong time in the wrong place. And then getting kind of high on success." 10 When their newly founded investment company started to attract large sums of money overnight, their bonds to conventional standards appear to have been increasingly loosened and subsequently they "kind of went overboard in [their] success" and embezzled a large amount of money from their own investment company and engaged in tax evasion.

The degree to which bonds were attenuated seems to vary between participants. While some respondents, like James, seemed to have loosened bonds, other respondents seemed to experience a disrupted or fractured bond to society. In four participants $(15 \%)$, this process started at an early age. Their narratives illustrate how poor parenting, 'code of the street' (in the words of Morris; see also [58]) and institutionalization appear to have broken down social bonds and kick-started a life of crime. Through a continuous process, bonds seem to have remained weak until adulthood, contributing to often extensive criminal careers ([16], p. 124).

More commonly, however, the distancing process appears to have started in adulthood, for example, as the outcome of events or developments that became turning points changing the direction of participants' lives. Walter's narrative illustrates how this process can unfold. He was a successful entrepreneur in the ICT sector when he was arrested for an alleged white-collar offence. Eventually charges were dropped, but as a consequence he had to sell his company and he could not maintain his luxurious lifestyle:

I was very angry after the first time. (...) I had been very serious until the first arrest. I had a financial structure with the bank, we really had a lot of customers, we had a seriously big accountancy firm. After that, I kind lost it for a long time. I thought: I don't care anymore. If that's the way it's going to be, then that's how I'm going to do it. Interviewer: A form of resistance to what had happened? Walter: Yes, I think so. If they consider me to be a criminal, then I might as well be one. ${ }^{11}$

\footnotetext{
$\overline{10}$ This statement suggest that a process of social learning [5] may also have played a role in James' drift away from conventional society. While James did not explicitly refer to such a learning process, the conspirator did have a record of misconduct and may have influenced James's thoughts and actions.

11 This statement suggests that a process of labelling may have played a role in process of distancing from conventional society [59].
} 
Years later, he went back to the sector he had worked in previously, which he knew to be criminogenic. He got in touch with former business associates to start a new line of business. Although his life had changed for the better during this period (a new, more conventional girlfriend, the birth of a daughter), he was still far removed from conventional social standards:

I would never kill anyone or anything like that. I wouldn't even hurt a spider. Hard drugs were a no-go area. But arms trafficking, I could do that. Weed, no problem. Steal money from the government? No problem at all. I really believed that.

He was arrested and convicted for making false statements to the tax authorities and money laundering.

Socialization processes in adulthood also seem to have contributed to losing touch with conventional order and important others. Peter's narrative illustrates how the combination of a life-event and experiences in a company kick-started an extended period of white-collar offending. After successfully working in several sectors, he made a career move and went to work at a bank. Around that time, he lost a substantial amount of money (which he had just inherited) in the stock market:

That totally changed me. I couldn't stand that I had lost my money and that a bank could just create money out of nothing. Or cheat so much. And I thought: I can do that too. I'll get you. That was part of the idea. Revenge.

The corporate culture at the bank, where customers were treated 'really nastily', affected him: "I noticed that I was getting tougher myself. I thought that if this is how they deal with it, then I can also make money this way." (see also research that suggests that socialization processes in organisations may contribute to a distancing to conventional society; [19-21]). Feeling vengeful and hardened, he made his first fraudulent step, forging a contract to con a bank. This first step led to another in a process that gradually worsened until finally he was involved in two large investment scams for which he was convicted. Recounting the change in his life from childhood to a prison cell, he says:

I think I always was a very nice, considerate boy. I always had many friends. I was surrounded by a loving family. I had long-term relationships. Twenty-year friendships and relationships that lasted three to four years. (...) So it makes me think - stuff happened. I'm no angel anymore. I am very angry. Angry at society.

The cases of James, Walter and Peter exemplify three important sides of a weakened bond to conventional society and the way it increases the risk of crime involvement. First, it seems that it is not an event, incident or socialization process per se that leads to a distancing from conventional society. It is the way respondents experience and react to these circumstances that sets them adrift [28]. Second, the distancing to conventional society appears to be a psychological state: respondents experienced unrest, felt unrestrained or sensed a distance. Lastly, the distance to conventional society has a 
clear moral dimension: they expressed a weakened commitment to the laws, rules and norms of conventional society ([17, 18]: the element of belief). However, a lowered commitment to the laws, rules and norms of conventional society is not restricted to respondents with weakened social bonds. Participants who were apparently well bonded to society and seemed to live more conventional lives also expressed deviant norms and attitudes.

Moral Mechanisms beyond the Immediate Context Throughout the interviews, participants expressed, referred to and talked about attitudes to and beliefs about what they consider normal, permissible and fair behaviour in the financial-economic realm. The world of doing business clearly appears to be a moral domain to the respondents, rather than a realm that is guided by mere instrumental motives or opportunities. Respondents typically reported that they underwrite the importance of obeying the law and paying taxes, but at the same time expressed attitudes and norms that contradict these values. Characteristically, these norms and attitudes seemed to provide them with flexibility, room or leverage to choose what is permissible behaviour in particular situations, rather than following laws and regulations per se.

Though the components of Rest's model were identifiable in the narratives, they often did not fully capture the complexities of respondents' moral position nor the attitudes regarding the specific moral domain under study, that is compliance to laws in the financial-economic realm. ${ }^{12}$ Based on the analysis of the moral considerations expressed by respondents, four moral mechanisms that build upon as well as elaborate Rest's framework were identified.

Moral Nonchalance The mechanism of moral nonchalance resulted in participants apparently not precluding a fraudulent act on moral grounds ([48]: moral sensitivity, moral judgement, moral character). Such nonchalance, expressed by 18 respondents $(69 \%)$ is recognizable in the tone respondents use to talk about fraudulent acts, the repeated (smaller) transgressions they engaged in, and the belief that other businessmen transgress as they do. For example, Roger, an entrepreneur who was always seeking out new business opportunities and pushing the limits of legality, expressed his moral nonchalance as follows, when talking about transgressions earlier in his professional career:

Look, I always say an entrepreneur is never a saint. When you start digging in a company, you'll always find something. That's how it works. Things need to keep going, right? So sometimes you get creative - if you know what I mean. Of course it's forbidden. But hey, Phillips does it too; even the government does it.

This moral nonchalance seems to have spurred the decision to illegally take out company property from one of his companies during a time of economic strain at the time of the selection offence:

\footnotetext{
${ }_{12}$ Participants sometimes distinguished between attitudes and norms in the financial-economic life and those in the private life domain and indicated that they saw a line of conduct as permissible in the business context but not in the private life domain (e.g. [60]). The present paper focusses on the attitudes and norms participants expressed regarding the financial-economic realm.
} 
And then I didn't have any money. Then I used the money from that van to spend privately. And of course I kind of knew. But there you go. When you have employees and you pay taxes for them as you should, and you are an employer, then they [the government] like you. But when things go wrong, you're out on your own. You need help, but you don't get any. As an entrepreneur, you're used taking care of yourself and solving your own problems. So that's what I did. I took the punishment. I needed the money and that's how I got it.

When a fraudulent act is not precluded on moral grounds, compliance to laws and regulations is likely to become instrumental, arguably making external controls the principle obstacle to an individual's misconduct [31]. Take Joseph's statement about whether to comply with environmental regulations for spray booths on his business park:

You don't look at what is good or bad for the environment; you look at it from an economic point of view. Something is compulsory. If there hadn't been a law about spray booths, I would have flushed it down the drain.

When discussing the selection offence, Joseph gives another telling account. When he saw that a major building job on his business park would be a costly affair, he was tempted to cut costs by hiring a dubious contractor he knew:

We are all on the edge. All businessmen. You let someone else fix it, you get bills and you think you are covered. But in principle, you don't even really look into it properly to see what you will find out. (...) Of course, you can follow a straighter path, but you could still get into trouble! Though you'd have to be really thick. Still, that's what you get when you always want something for nothing. You also don't want to look beyond what is compulsory. That's it.

Joseph was convicted for large-scale turnover tax evasion.

Supreme Moral Judgement In the second mechanism, a participants' moral judgement - his or her beliefs about the world, the government or other social institutions appears to be the ultimate arbiter of permissible and fair behaviour in the financialeconomic realm, expressed by 14 respondents (54\%) ([48]: moral judgement). These beliefs are often directly associated with ideas about the (un)fairness of the law and regulations, the actions of government agencies or the workings of society and politics more generally (see also the influence of legitimacy on financial-economic misconduct, [46, 61]). Where the mechanism of moral nonchalance is characterized by a flexible moral compass, here the moral compass appears firm but seems to points away from the law.

Take Phillip, a businessman who was convicted for his role in an illegal organization that helped other businessmen evade taxes through fraudulent schemes (for a fee). His participation in the fraud started 15 years ago when he faced economic hardship in his agricultural business. He was easily convinced to participate in a scheme to con the tax 
authorities in exchange for money: "They do it too. And when you see your company go bankrupt, you do things to save it." ${ }^{13}$ In his view, the tax authorities and the government are corrupt and therefore defrauding them is justified:

Well look, if the government and the tax authorities stuck to the rules, then we would too. But you don't see any of that when you look around. Interviewer: Can you elaborate? Phillip: Well things like Greece. Otherwise I would already have taken early retirement at my age. Just look around. The taxes we pay and how much of it goes to Greece. Rutte [Dutch prime minister] is just lying. It's a big disaster. That's my view.

If you con the tax authorities for a thousand euros, they make you out to be the biggest criminal, and they do it all day long for hundreds of millions. Interviewer: And does that influence ... Phillip: Yes, that influences me. When I read a piece in the paper about how someone conned the tax man, or a bank or an insurance company, it makes me smile. No individuals though! No... it's great. They do the same, on a much larger scale.

Other participants stressed the permissibility of a fraudulent act because they considered a specific law or regulation to be unfair. Brian's case illustrates this. As the owner of a construction company, he was involved in price-fixing schemes several years ago: "I actually think it's fair. I'm not afraid to admit that. It is about getting your bills reimbursed." He argued that public tenders placed financial strain on construction companies as they incurred expenses without knowing whether they would get the job:

Of course that's also a kind of fraud, but to me it isn't fraud. Interviewer: Why?

Brian: Because you had done a lot of work and only one benefitted. Interviewer:

So it was fair to do it that way? Brian: As far as I know, yes. But it wasn't allowed.

Judging what is permissible behaviour by one's own standard of fairness also seemed to have played a role in the selection offence, a tax evasion of several hundred thousand euros. He was approached by a businessman to do construction jobs off the books: "Look, usually you don't do undeclared work. But with this guy, it was the first time really. I had done a couple of things under the table, but that was peanuts." He felt he had to accept it out of a sense of responsibility for his employees: "Look, I always need work. To keep the people going, so I thought well I better do this."

Moral Blockade In the third moral mechanism, moral blockade, emotional states - anger, bitterness or defiance - seem to hinder or block a moral approach to the decision to engage in or refrain from a fraudulent act, and even encourage it (for the influence of feelings of defiance on crime, see also [62]). The moral blockade, recognizable in 7 respondents (27\%), typically seems to originate

\footnotetext{
${ }^{13}$ In some instances, supreme moral judgement and moral nonchalance may resemble each other in certain words (e.g. "They do it too"). However, in the case of supreme moral judgement these words seem to reflect a personal conviction or belief about important values regarding institutions and laws (e.g. fairness). In contrast, in the case of moral nonchalance such words appear to reflect an incomplete internalization of norms regarding tax laws and regulation, rather than a deeply felt belief that points away from the law.
} 
from and to be fuelled by earlier negative events and experiences. This seems to result not only in an open and sometimes blatant rejection of the law, but also in reduced empathy for the victims, especially the government and larger institutions such as banks or insurance companies ([48]: a combination of moral sensitivity, moral judgement).

The narrative of Benjamin illustrates how a moral blockade appears to have lied at the root of an extensive white-collar crime career that, despite his relatively young age (30), included more than 35 scams (the last was the only one he was arrested for: a mass-market consumer fraud). When he conned thousands of companies by promising them a service worth a relatively small amount of money that they would never receive, he knew it was wrong but he explains he did not feel for the victims:

The moral side doesn't count so much. I took their money. That is a little contradictory: I did it knowingly, and knowing that it was wrong. There is no lack of it, it's there. But the choice was just very simple.

Benjamin explained that a reduced empathy for his victims originated from earlier stages in life:

I have become so hard-hearted in that respect. When I look back, there is no feeling of shame or remorse. That has gone completely. Interviewer: What made you so hard-hearted? Benjamin: You can trace it back all the way to my childhood. People caused me so much pain and sorrow in my youth. Really so much. A person only has a limited amount of emotions in one lifetime. And mine had already been burned up by the time I was 10 years old. It's just gone. I can be very tough.

Although the factors behind the moral blockade typically seem to be negative circumstances, participants express to they have experienced joy, tension and excitement after a while, which encouraged them to pursue the fraudulent activities (for the role of emotions in committing a crime, see [63]). For example, Oscar, an entrepreneur in the transport sector, used his extensive professional knowledge to simultaneously run legitimate and illegitimate businesses. He says that he used to be a law-abiding citizen until his father's transport company, where he had been employed, went bankrupt. The company's closure and its failure to relaunch resulted in anger and bitterness, but also in a large debt. After exploring legal and illegal options to resolve his debt, he started to buy up companies, "empty them" and file for bankruptcy. When the opportunity arose to carry on a part of his father's old company, he had already taken a different path:

In principle, at that time, I had the 50 trucks .... I could have built up that company in ways you wouldn't believe. But I was so bitter really that I didn't give a shit about anything. And then I also really started enjoying it. 
He started off on an extensive criminal career that involved around 200 bankruptcy frauds including the selection offence: "It became a game and you lived off it."

Adapted Moral Self A fourth and last moral mechanism, adapted moral self, is related to how respondents see themselves in moral terms. A significant segment of participants $(n=11 ; 42 \%)$ referred to themselves in an idiom that indicates that they do not necessarily see themselves as fully law-abiding: "I am a benign criminal", "If I were to do it again, I would do it on a larger scale", "I will always find a way to make money, legally or illegally" and "I was always the naughty boy at home." In such instances the self-regulatory function of the moral self that withholds individuals from misconduct is arguably reduced ([48]: moral motivation; [45, 64]: moral self). An exemplary illustration of the dynamic nature of the moral self and its role in misconduct is presented in the case of James:

As a child, you are taught to obey the law. But as a child you also develop your own personality within which you construct a certain morality. And I think that for many people this can go together later in life. But for many, it will also start to collide.

When I don't agree with certain regulations, both in business and private contexts, if I find it unjust, then I think my personality or character drive me in a direction where you start to seek out the margins of the regulations, to make it easier for yourself or to gain something from it or to bypass the law. In that I think... I do not see a big difference between private or business contexts. I think it is more of a character trait.

Besides the aforementioned "unrest" and "high", James' adapted moral self-image is likely to have been important in his engagement in evading property taxes, one of the offences he was convicted for. The way he saw himself in moral terms seems to have offered him the "space" to evade taxes, but also to have freed him to help others conceal money from the government: "If somebody asks me 'Can you help me with this?', then I do not have the moral [integrity] to think: I am an upstanding, law-abiding citizen, I don't do that kind of thing. No way".

\section{Summary}

The analysis illustrates how change, pressure and opportunity, weakened bonds and adjusted morality may contribute to white-collar crime involvement. At the time of the selection offence, participants typically experienced some form of change which, in turn, led to pressures that were resolved or taken advantage of by exploiting criminal opportunities open to them. Although this sequence is important, the analysis clearly suggests that involvement in white-collar crime cannot be fully understood without taking the offenders' personal background (bonds) and cognition (morality) into account. Regarding the bond to conventional society, respondents seem to have experienced weakened bonds to important others and to 
the standards, norms and rules of conventional society in varying degrees, ranging from a short-term distancing to prolonged and profound drifts away from conventional society. Concerning morality, the findings indicate that some respondents had outspoken prosocial norms but that most participants appear to have adjusted moral ideas of what is permissible in the financial-economic realm. The study identifies four moral mechanisms that appear to go beyond the context, facilitating white-collar crime involvement: moral nonchalance, supreme moral judgement, moral blockade and adapted moral self.

The analysis also shows how the three factors interacted and resulted in distinct white-collar offending patterns. In some participants, the involvement in a white-collar offence appears to have been an isolated affair and was either the result of a crisis in which bonds were severely strained, or occurred in a transitional phase in which bonds to conventional society were weakened more gradually. Context-dependent moral adjustments seem to have freed these participants to act in ways they would not normally have acted. However, more commonly, white-collar crime involvement appears to be part of a long-running process. The narratives illustrate how weakened bonds and flexible moral ideas increased the chance that a person ended up in a criminogenic position or engaged with other deviants and how this affected the way participants responded to pressures (strain, social pressure or temptation) and to criminal opportunities. Some of these respondents were involved in extended criminal careers, experiencing prolonged and profound drifts, sometimes starting in their youth but mostly in adulthood. In these participants in particular, moral blockade and adapted moral self appear to have played an important role. The analysis also identifies respondents with an intermittent pattern of misconduct who appear to have been loosely tied to their social and economic surroundings or who had conventional ties but nonetheless flexible and deviant norms. These respondents were typically characterized by moral nonchalance and supreme moral judgement.

\section{Discussion}

Based on an analysis of interviews with 26 convicted white-collar offenders, this study aimed to provide an in-depth description of the process of involvement in white-collar crime on a personal level. While a study such as the present one that uses retrospective data gathered from interviews is limited in establishing temporal and causal order, this explorative study provides rich data and new perspectives on the thoughts and actions of white-collar offenders. By applying well-researched theories to the real-life circumstances of financial-economic misconduct, it contributes to the ecological validity and qualitative understanding of the utilized concepts. Two main findings stand out.

First, the findings show that involvement in white-collar crime is typically part of a long-running process across respondents' lives, rather than a purely contextual response to business-related lures or pressures. The narratives show that it is the interaction of emerging criminogenic business-related pressures and opportunities [2, 9], and two personal-level factors - weakened bonds to society and adjusted moral ideas - that appear to have led to white-collar offending $[16,48]$. This process of crime involvement is characterized by both change and continuity. On the one hand, respondents experienced changes in adulthood (life-events and socialization processes) that appear 
to have weakened social bonds or changed moral attitudes and norms, increasing the risk of selecting into and actually taking advantage of criminal opportunities, something they may not have engaged in previously. On the other hand, considerable continuity is also identifiable. Not only for the respondents who seem to have experienced a social, psychological and moral distance to conventional society from early stages of life. Also, respondents, who had apparently successfully adapted to adult economic and social roles, experienced states of "unrest" or drifts over prolonged periods and expressed adjusted moral views that seem to have become part of their world view, professional lives and of themselves [28].

For white-collar criminology, these findings underscore the importance of looking beyond criminogenic business-related circumstances to understand white-collar crime involvement, and taking into account the personal thoughts and actions of white-collar offenders [8] and relevant earlier life-course developments [10]. Although the current study illustrates the possible influence of social interactions, life-events and socialization processes on bonds, morality and crime, it is limited in establishing how and in which order these factors influence each other. Future research is called for to demonstrate causal relationships between these factors, and to establish whether (or to what degree) offenders select into criminogenic industries, organisations and networks because of weakened bonds or flexible and deviant morals, or that these personal crime-inducing factors are the result of such criminogenic conditions (or that both processes work at the same time, see [65], p. 173).

Second, the findings highlight the important but complex role of personal morality in white-collar offending. On the one hand, the narratives illustrate how prosocial moral considerations seem to have inhibited misconduct earlier in respondents' lives, even in the case of available criminal opportunities, a low risk of detection and exposure to criminogenic pressures. On the other hand, the narratives suggest that flexible and deviant moral views appear to open up the possibility of crime, and enhance the risk of engaging in white-collar offending [13]. Following Rest's suggestion to take his model "as a framework for programmatic research" ([48], p. 4), the study used his concepts to understand the moral considerations that are involved in white-collar offending. The narratives illustrate how a lowered sensitivity for the nature or consequences of a fraudulent act (moral sensitivity), a failed internalization of norms or a deviant belief or about what is permissible behaviour (moral judgement), a choice of another valued option above following the law (moral motivation) and a lack of self-restrain (moral character) all may increase the risk of white-collar offending. However, while the narratives typically entailed the separate components of Rests' model, independently they failed to capture the complexities of respondents' situation and moral position, and the specific attitudes respondents adopted in the particular moral domain under study. This study exploratory identifies four moral mechanisms: moral nonchalance, supreme moral judgement, moral blockade and adapted moral identity. These moral mechanisms typically appear to be intricately related to a person's life experiences, thinking and background, which highlights the need to take into account earlier life-course developments when examining moral considerations of white-collar offenders (for a pioneering white-collar crime study with a life-course perspective on moral views in white-collar offenders, see: [37]). 
A notable finding of the study is that the narratives suggest that the flexible and moral views on what is permissible financial-economic behavior often appear to go beyond the immediate context and predate the selection offence. For example, respondents often explicitly stated they had such moral ideas before the selection offence (for example, in the case of Oscar and Benjamin). Also, even if respondents didn't explicitly state that they had flexible or deviant ideas before the selection offence, the narratives demonstrate clear consistencies in moral views when respondents describe their thoughts when they transgressed already years before the selection offence, and when describing the selection offence (for example, in the case of Roger and Brian). Such explicit statements and parallels in moral views also seem consistent with the intermittent to frequent pattern of misconduct these respondents talk about. Moreover, the fact that moral mechanisms may predate the selection offence, is line with a large body of experimental research that has established causal relationship between Rest's psychological processes and financial-economic misconduct in experimental studies $[49,50]$.

In sum, the identified mechanisms provide a new perspective to understand the nature and role of personal moral views of executives, managers and white-collar workers in relation to crime and deviance within organizations and industries. However, while the identified moral mechanisms are based on Rest's theory, which is one of the most prominent and best researched theories in the ethical decisionmaking literature, the current study is explorative in nature. The moral mechanisms should be validated in future research, using new samples and other research designs. Moreover, as the study uses retrospective data gathered from interviews, causal order between the moral mechanisms identified in this study and white-collar offending remains inconclusive. Future research should examine the causal order between the identified moral mechanisms and financial-economic misconduct using experimental research designs.

While our findings are consistent with Rest's framework, it is important to discuss alternative explanations for the results. Possibly, the respondents' statements do not reflect their personal moral views, but are in fact statements to justify the criminal act in retrospect, perhaps in an attempt to manage impressions towards themselves or a social audience (e.g. [38]). While this possibility cannot be excluded, the narratives suggest something different. While respondents may have wanted to present themselves favourably to some degree (of course, it is not known what they have abstained from telling), almost all respondents recognized their misconduct and spoke openly about their intentions to engage in the offence (for example, the case of Lawrence and Rudolph). Moreover, the majority of respondents referred repeatedly to earlier transgressions and crimes, and expressed deviant attitudes and norms, all matters which participants would arguably not have revealed when making excuses or managing impressions.

Alternatively, the statements made by the respondents may reflect mental strategies respondents deployed during the selection offence, as suggested by neutralization theory, rather than their personal moral views [9, 32]. In line with the premises of neutralization theory, the narratives of respondents with otherwise prosocial ideas and lives do in fact suggest that they used pre-emptive self-talk to assuage anticipated guilt during the act (for example, the case of Fred [defence of necessity] and Merry [denial of responsibility]). Conversely, in many other instances neutralization theory seems to 
fall short of offering a comprehensive explanation. For example, as the theory regards all offenders as fully socialized individuals, it struggles to account for those respondents (and white-collar offenders more generally) who openly express deviant moral views in the financial-economic realm (for example, the case of Oscar). Moreover, as neutralization theory proposes that all offenders have similar and stable moral views, the theory cannot easily account for the significant heterogeneity and change in what the respondents considered permissible behaviour in the financial-economic realm (for example, the case of Walter). ${ }^{14}$ Last, as neutralization theory recognizes only one psychological process (i.e. mental strategies to reduce cognitive dissonance; [68]), the theory ignores the role of alternative psychological processes in moral decision-making, which have been established empirically in earlier studies and are apparent in the current one.

Rather than justifications after the act or neutralizations during the act, the current findings suggest that the moral views expressed by those who repeatedly engaged in rule-violating behaviour are expressions of personal beliefs, norms and feelings about their professional life, the financial-economic realm and themselves. For example, when Phillip expresses his disdain for the government, it seems to reflect his worldview, rather than a way of excusing his behaviour or freeing him from mental restraints. Or, when Benjamin states that he lost all feeling for others since his youth, his statements arguably express how he felt, rather than a mental strategy to reduce guilt or an example of impression management. However, using retrospective data, this study cannot establish this definitely. Future research with longitudinal and experimental research designs should establish whether (and to what degree) white-collar offenders' pre-existing personal beliefs, norms and feelings cause white-collar offending, or that white-collar offenders neutralize or justify their crime involvement during or after the criminal act.

Taken together, the current study submits that personal morality plays a more divers, complex and multi-faceted role in white-collar offending, than suggested by neutralization theory. Yet, the study also identifies ways in which neutralization theory is compatible with the identified moral mechanisms and more broadly Rest's theory. First, neutralizations are likely to be relevant in Rest's stage of moral motivation. Rest [48] argues that at this stage individuals may choose another valued option over obeying the law, even if a fraudulent act is regarded as impermissible under normal circumstances. Individuals may find neutralization techniques to be helpful in reducing cognitive dissonance that is caused by choosing a line of action that one sees as impermissible under normal circumstances (for example, the case of Fred). Second, neutralization techniques are likely to play a role in the development of flexible or deviant moral mechanisms. Neutralization techniques may have been facilitating in the gradual process of becoming committed to unconventional norms or in the course of adapting a non-prosocial moral self-image (for example, the case of James). In the past, participants may have had a need to neutralize or rationalize in order to bring their

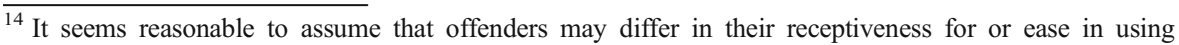
neutralizations or justifications. While neutralization theory does not allow for personal differences, the conceptually similar moral disengagement theory [66] proposes that individuals differ in the ways they can access or use strategies to justify their actions. Such an explanation would be more easily compatible with the current and earlier findings that show personal differences in moral views within white-collar offender samples (e.g. [37]) and between white-collar offenders and non-offenders (e.g. [67]).
} 
values and behaviour into agreement. This would, in turn, have weakened their commitment to prosocial values until finally there was little or no longer a need to neutralize, a process described by Hirschi as a "hardening process" ([18], p. 208). Future research is needed to examine whether and how neutralization techniques may erode initially prosocial personal moral views.

Finally, neutralization techniques and the identified moral mechanisms may be compatible in the sense that they function as communicating barrels. For example, Minor [34] proposes that the more an individual has accepted and internalized as a specific norm (he is about to break), the more he or she would be dependent on the availability of a neutralization. However, the more a person has not accepted or internalized a norm, the more easily he or she may engage in transgressive behaviour without the need for neutralizations. In terms of the current findings, if a whitecollar offender thinks that a fraudulent act is permissible (for example, in the case of Phillip), if a white-collar offender does not feel the moral consequences of a fraudulent act (for example, in the case of Benjamin), or if an white-collar offender has adjusted his or her moral self-image (for example, in the case of James), there would be less or no need to neutralize or justify misconduct. Put differently, the use of neutralizations would seem to depend on an individual's norm acceptance or norm internalization, his or her capacity to recognize and care about the moral consequences of his or her actions and his or her moral self-image. Future longitudinal and experimental research is needed to examine whether and how neutralization techniques and moral mechanisms may operate like communicating barrels.

In closing, it is important to address issues concerning validity and generalizability. First, the study provides an in-depth perspective on the process of crime involvement, based on subjective descriptions and interpretations of what occurred in respondents' lives. The narratives may contain errors, be distorted by time and by events that followed after the selection offence (to some degree). It is difficult to fully control for these possible limitations in interview studies that use retrospective data. However, such interview studies do provide one of only a few available ways to understand the process of criminal involvement on a personal level and is widely used methodology in criminology (see e.g. [55, 69]). More research in new samples and using other research design is called for to validate the current findings.

Second, the size and nature of the sample limits the generalizability of the findings. While consistent with qualitative research in the field, the sample is small in size [52]. However, as outlined in the method section, the criminal, organizational and demographic profile of respondents does correspond to that of white-collar offenders in a contemporary large-scale study in the Netherlands [54]. Also, the profile of the respondents is similar to that of white-collar offenders in other jurisdictions, such as the United States (e.g. [2, 14, 29]). Because of these similarities and social and economic similarities between the Netherlands and other western societies with market-based economies, the current findings may have significance for other samples and jurisdictions. However, future research with new samples and in other jurisdictions is needed to examine to what degree the current findings can be generalized. Although the study may have some generalizability beyond the sample, its main contribution to the literature is that it provides an in-depth description of the poorly understood process of white-collar crime involvement on a personal level. 
Acknowledgements The author wants to thank Nikita van Weenen for her highly valuable and inspiring contribution to this paper, and the three anonymous reviewers for their very helpful comments.

Open Access This article is licensed under a Creative Commons Attribution 4.0 International License, which permits use, sharing, adaptation, distribution and reproduction in any medium or format, as long as you give appropriate credit to the original author(s) and the source, provide a link to the Creative Commons licence, and indicate if changes were made. The images or other third party material in this article are included in the article's Creative Commons licence, unless indicated otherwise in a credit line to the material. If material is not included in the article's Creative Commons licence and your intended use is not permitted by statutory regulation or exceeds the permitted use, you will need to obtain permission directly from the copyright holder. To view a copy of this licence, visit http://creativecommons.org/licenses/by/4.0/.

\section{References}

1. Edelhertz, H. (1970). The nature, impact and prosecution of white-collar crime. Washington: US Department of Justice.

2. Weisburd, D., Waring, E., \& Chayet, E. (2001). White-collar crime and criminal careers. New York: Cambridge University Press.

3. Sutherland, E. H. (1983). White-collar crime: The uncut version. New Haven, CT: Yale University Press.

4. Clinard, M. B., \& Yeager, P. C. (1980). Corporate crime. New York: Free Press.

5. Sutherland, E. H. (1947). Principles of criminology. Chicago: Lippincott Co..

6. Benson, M. L., \& Simpson, S. S. (2009). White-collar crime: An opportunity perspective. New York: Routledge.

7. Agnew, R., Piquero, N. L., \& Cullen, F. T. (2009). General strain theory and white-collar crime. In S. S. Simpson \& D. Weisburd (Eds.), The criminology of white-collar crime (pp. 35-62). New York: Springer.

8. Benson, M. L., \& Manchak, S. M. (2014). The psychology of white-collar crime. In Oxford Handbooks Online in Criminology and Criminal Justice. https://doi.org/10.1093/oxfordhb/9780199935383.013.008.

9. Cressey, D. R. (1953). Other people's money. A study in the social psychology of embezzlement. Glencoe: The Free Press.

10. Benson, M. L. (2016). Developmental perspective on white-collar criminality. In S. R. Van Slyke, M. L. Benson, \& F. T. Cullen (Eds.), The Oxford handbook of white-collar crime (pp-253-274). Oxford: Oxford University Press.

11. Blokland, A. A. J., \& Nieuwbeerta, P. (2010). Life course criminology. In S. G. Shoham, P. Knepper, \& M. Kett (Eds.), International handbook of criminology (pp. 51-94). London: CRC Press.

12. Gottfredson, M. R., \& Hirschi, T. (1990). A general theory of crime. Stanford: Stanford University Press.

13. Wikström, P.-O. H. (2006). Linking individual, setting and acts of crime. Situational mechanisms and the explanation of crime. In P.-O. H. Wikström \& R. J. Sampson (Eds.), The explanation of crime: Contexts, mechanisms, and development (pp. 61-107). Cambridge: Cambridge University Press.

14. Benson, M. L., \& Kerley, K. R. (2001). Life-course theory and white-collar crime. In H. N. Pontell \& D. Shichor (Eds.), Contemporary issues in crime and criminal justice: Essays in honor of Gil Geis (pp. 121136). Upper Saddle River, NJ: Prentice Hall.

15. van Onna, J. H. R., van der Geest, V. R., Huisman, W., \& Denkers, A. J. M. (2014). Criminal trajectories of white-collar offenders. Journal of Research in Crime and Delinquency, 51, 759-784.

16. Sampson, R. J., \& Laub, J. H. (1993). Crime in the making. Pathways and turning points through life. London: Harvard University Press.

17. Durkheim, E. (1951). Suïcide. New York: Free Press.

18. Hirschi, T. (1969). Causes of delinquency. Berkeley: University of California.

19. Braithwaite, J. (1989). Crime, shame and reintegration. Cambridge: Cambridge University Press.

20. Passas, N. (1990). Anomie and corporate deviance. Contemporary Crises, 14, 157-178.

21. Punch, M. (1996). Dirty business. Exploring corporate misconduct: Analysis and cases. London: Sage Publications.

22. Lasley, J. R. (1988). Toward a control theory of white-collar offending. Journal of Quantitative Criminology, 4, 347-362.

23. Piquero, A., Piquero, N. L., \& Weisburd, D. (2016). Long-term effects of social and personal capital on offending trajectories in a sample of white-collar offenders. Crime \& Delinquency, 62, 1510-1527. 
24. Van Onna, J. H. R., \& Denkers, A. J. M. (2019). Social bonds and white-collar crime: A two-study assessment of informal social controls in white-collar offenders. Deviant Behavior, 40, 1206-1225.

25. Engdahl, O. (2011). White-collar crime and informal social control: The case of "crisis responders" in the Swedish banking and finance sector. Sociology Mind, 1, 81-89.

26. Engdahl, O. (2015). White-collar crime and first-time adult-onset offending: Explorations in the concept of negative life events as turning points. International Journal of Law, Crime and Justice, 43, 1-16.

27. Elder, S. H. (1994). Time, human agency, and social change: Perspectives on the life course. Social Psychological Quarterly, 57, 4-15.

28. Ulmer, J. T. (2014). Symbolic interactionism and crime in the life course. In M. Delisi \& K. M. Beaver (Eds.), Criminological theory: A life-course approach (pp. 211-226). Sudbury: Jones and Bartlett Publishers.

29. Benson, M. L. (1985). Denying the guilty mind: Accounting for involvement in a white-collar crime. Criminology, 23, 583-607.

30. Kish-Gephart, J. J., Harrison, D. A., \& Treviño, L. K. (2010). Bad apples, bad cases, and bad barrels: Meta-analytic evidence about sources of unethical decisions at work. Journal of Applied Psychology, 95, $1-31$.

31. Paternoster, R., \& Simpson, S. S. (1996). Sanction threats and appeals to morality: Testing a rational choice model of corporate crime. Law \& Society Review, 30, 549-583.

32. Sykes, G., \& Matza, D. (1957). Techniques of neutralization: A theory of delinquency. American Sociological Review, 22, 664-670.

33. Klockars, C. B. (1974). The professional fence. New York: The Free Press.

34. Minor, W. W. (1981). Techniques of neutralization: A reconceptualization and empirical examination. Journal of Research in Crime and Delinquency, 18, 295-318.

35. Kaptein, M., \& van Helvoorts, M. (2019). A model of neutralization techniques. Deviant Behavior, 40, 1260-1285.

36. Schuster, A., \& Levi, M. (2013). Beyond the fraud triangle: Swiss and Australian elite fraudsters. Accounting Forum, 39, 176-187.

37. Zeitz, D. (1981). Women who embezzle or defraud: A study of convicted felons. New York: Preager.

38. Goldstraw-White, J. (2012). White-collar crime. Accounts of offending behavior. London: Palgrave Macmillan.

39. Klenowski, P. M., Copes, H., \& Mullins, C. W. (2011). Gender, identity, and accounts: How white collar offenders do gender when making sense of their crimes. Justice Quarterly, 28, 46-69.

40. Klenowski, P. M., \& Copes, H. (2014). Looking Back at other People's money: A qualitative test of Cressey's classic hypothesis of trust violating behavior. Journal of Qualitative Criminal Justice \& Criminology, 1, 29-52.

41. Fritsche, I. (2005). Predicting deviant behavior by neutralization: Myths and findings. Deviant Behavior, 26, 483-510.

42. Piquero, N. L., Tibbetts, S. G., \& Blankenship, M. B. (2005). Examining the role of differential association and techniques of neutralization in explaining corporate crime. Deviant Behavior, 26, 159188.

43. Wenzel, M. (2005). Motivation or rationalization? Causal relations between ethics, norms and tax compliance. Journal of Economic Psychology, 26, 491-508.

44. Maruna, S., \& Copes, H. (2005). What have we learned from five decades of neutralization research? Crime and Justice, 32, 221-320.

45. Blasi, A. (1980). Bridging moral cognition and moral action: A critical review of the literature. Psychological Bulletin, 88, 1-45.

46. Tyler, T. R. (2009). Self-regulatory approaches to white-collar crime: The importance of legitimacy and procedural justice. In S. S. Simpson \& D. Weisburd (Eds.), The criminology of white-collar crime (pp. 195-215). New York: Springer.

47. Wenzel, M. (2004). An analysis of norm processes in tax compliance. Journal of Economic Psychology, 25, 213-228.

48. Rest, J. (1986). Moral development: Advances in research and theory. New York: Preager.

49. Craft, J. L. (2014). A review of the empirical ethical decision-making literature: 2004-2011. Journal of Business Ethics, 117, 221-259.

50. O'Fallon, M. J., \& Butterfield, K. D. (2005). A review of the empirical ethical decision-making literature: 1996-2003. Journal of Business Ethics, 59, 375-413.

51. De Poot, C. J, Van Prooijen, J. W., \& De Keijser, J. (2017). Experimenten in de criminologie [Experiments in criminology]. Tijdschrift voor Criminologie, 59,(2) 1-9. 
52. Copes, H., Brown, A., \& Tewksbury, R. (2011). A content analysis of ethnographic research published in top criminology and criminal justice journals from 2000 to 2009. Journal of Criminal Justice Education, 22, 341-359.

53. Centraal Bureau voor de Statistiek (2017). Bedrijven, bedrijfsgrootte en rechtsvorm. [Companies, company size and legal form]. Retrieved from http://statline.cbs.nl/Statweb/publication/?DM= SLNL\&PA $=81588$ NED\&D1 $=0-24 \& D 2=0 \% 2 \mathrm{c} 3 \% 2 \mathrm{c} 9 \% 2 \mathrm{c} 13 \% 2 \mathrm{c} 52 \% 2 \mathrm{c} 54 \% 2 \mathrm{c} 59 \% 2 \mathrm{c} 63 \% 2 \mathrm{c} 70 \% 2 \mathrm{c} 77$ $\% 2 \mathrm{c} 80 \% 2 \mathrm{c} 90 \% 2 \mathrm{c} 94 \% 2 \mathrm{c} 98 \% 2 \mathrm{c} 108 \% 2 \mathrm{c} 117 \% 2 \mathrm{c} 119 \% 2 \mathrm{c} 121 \% 2 \mathrm{c} 127 \% 2 \mathrm{c} 132 \% 2 \mathrm{c} 136 \% 2 \mathrm{c} 139 \& \mathrm{D} 3=$ $1 \& \mathrm{HDR}=\mathrm{G} 2 \% 2 \mathrm{cT} \% 2 \mathrm{cG} 1 \& \mathrm{VW}=\mathrm{T}$

54. Van Onna, J.H.R (2018). Blurred Lines. A study of white-collar crime involvement (Doctoral Dissertation). Retrieved from http.www.research.vu.nl.

55. Laub, J. H., \& Sampson, R. J. (2003). Shared beginnings, divergent lives: Delinquent boys to age 70. Cambridge: Harvard University Press.

56. Shapiro, S. P. (1990). Collaring the crime, not the criminal. Reconsidering the concept of white-collar crime. American Sociological Review, 55, 346-365.

57. Matza, D. (1964). Delinquency and drift. New York: Wiley.

58. Anderson, E. (2000). Code of the street: Decency, violence, and the moral life of the inner city. New York: W.W. Norton.

59. Tannenbaum. (1938). Crime and the community. Boston: Ginn and Co..

60. Harré, R. (1983). Personal beings: A theory for individual psychology. Cambridge: Harvard University Press.

61. Tyler, T. R. (2006). Psychological perspectives on legitimacy and legitimation. Annual Review of Psychology, 57, 375-400.

62. Sherman, L. W. (1993). Defiance, deterrence, and irrelevance: A theory of the criminal sanction. Journal of Research in Crime and Delinquency, 30, 445-473.

63. Katz, J. (1988). Seductions of crime: Sensual and moral attractions of doing evil. New York: Basic Books.

64. Jennings, P. L., Mitchell, M. S., \& Hannah, S. T. (2014). The moral self: A review and integration of the literature. Journal of Organizational Behavior, 36, 104-168.

65. Steffensmeier D. J., \& Ulmer, J. T. (2005). Confessions of a dying thief: Understanding criminal careers and illegal enterprise. London: AldineTransaction.

66. Bandura, A. (2002). Selective moral disengagement in the exercise of moral agency. Journal of Moral Education, 31, 101-119.

67. Collins, J. M., \& Schmidt, F. L. (1993). Personality, integrity and white collar crime: A construct validity study. Personnel Psychology, 46, 295-311.

68. Festinger, L. (1957). A theory of cognitive dissonance. Stanford: Stanford University Press.

69. Van Koppen, M. V., \& De Poot, C. J. (2013). The truck driver who bought a café: Offenders on their involvement mechanisms for organized crime. European Journal of Criminology, 10, 74-88.

Publisher's note Springer Nature remains neutral with regard to jurisdictional claims in published maps and institutional affiliations. 